\title{
Perception of Physical Education Teachers on the Implementation and Evaluation of Curriculum 2013
}

\author{
Ermawan Susanto \\ Faculty Sports Sciences \\ Universitas Negeri Yogyakarta \\ Yogyakarta, Indonesia \\ ermawan.2017@student.uny.ac.id
}

\author{
Pamuji Sukoco \\ Faculty Sports Sciences \\ Universitas Negeri Yogyakarta \\ Yogyakarta, Indonesia \\ pamuji_sukoco@uny.ac.id
}

\begin{abstract}
K2013}$ has not gone as foresighted by the government. This research makes use of survey research mode in the form of field study. Interviews, observations and questioners obtained data. Data was collected in Sleman Regency from three primary schools namely: SD Muhammadiyah Balecatur, SD Negeri Mancasan, and SD IT Jabal Nur. Research. Subjects of the research include PE teachers and principals. The results showed that the views of teachers on the implementation of K2013 are considered inappropriate considering the fact that PE in elementary schools still needs an introduction to the basic skills of motion instead of thematic concept K2013. The findings of this research show that: (1) The subject of the study is that it is hard to explain the meaning of the philosophy of education using the body, (2) Appropriate answers to research questions that PE develops these three domains evenly; (3) Generally, the three elementary schools have expressed their interest in implementing K2013 from 2019 onward.
\end{abstract}

\section{Keywords - Perceptions, PE, Curriculum 2013.}

\section{INTRODUCTION}

Curriculum theory is one of the basic things that must be well understood when assessing curriculums. The scientific grounding behind the development of the curriculum is provided by curriculum theory, the curriculum formation struggle, the approach towards the curriculum, which is theoretical, the foundations in the curriculum that are theoretic, and the approach of the curriculum theory. When people understand the theory of curriculum, such people are expected to have the ability to comprehend the meaning of curriculum and this is the foundation in curriculum development. Physical education curriculum being studied as a praxis has a strong base. Firstly, the discussion of what is meant by the curriculum theory has to be presented as an introduction before the curriculum of PE is discussed, and the curriculum as a praxis. If the curriculum theory is understood adequately, it will make it possible to discuss the curriculum of physical education and the curriculum as praxis because it would have an adequate theoretical foundation.

Posner offers five curriculum approaches in order to understand the curriculum's importance to education. Posner's approaches are different from one another, but they are also coherent and interrelated [1]. The five perspectives are as follows: (1) traditional, (2) experiential, (3) structure of the disciplines (or disciplines, for short), (4) behavioral, and (5) cognitive. Posner provides the core question for each perspective in order to direct us to the meaning of each perspective. The perspectives and their core questions are as follows: (1) Traditional: What are the most important aspects of cultural heritage that should be preserved?; (2) Experiential: 'What experiences will lead to the healthy growth of the individual?; (3) Structure of the disciplines: What is the structure of the disciplines of knowledge?; (4) Behavioral: 'At the completion of the curriculum, what should the learners be able to do?; (5) Cognitive: How can people learn to make sense of the world and to think more productively and creatively?

A collection of accumulated nation-wide racial policies made available for children is what the curriculum should be like. Textbooks provide a number of general facts that are equally accessible to all children; hence, the opinion that dominates the daily newspaper news is answered by the content of the textbook. It was in the 20th century that the idea that the child's experience needs to be put into consideration by the curriculum began to flourish. The assumption that everything that happens to the child will affect their lives is the basis of the experiential view. Due to this, a wide range of content should be contained in the curriculum, not just what is planned for children at school and outside the school, but also all the unexpected consequences of any situation that will be faced by the child. Key positions, trends, and curriculum concepts are sought to be analyzed and synthesized by this academic approach. While implementing this approach, curriculum development is often based on historical and philosophical aspects and aspects of social conditions are also considered to some extent. The sphere of comprehensive schooling, including educational studies, is the basic concern of this approach. Lawrence Stenhouse [2] has produced one of the best explorations of the process model in curriculum theory and practice. It defines the curriculum uncertainly.

This research attempts to ask three study questions, which are serious problems to be identified and resolved with immediate effect. The three research questions are as follows: (1) Is the philosophy of education from the physical and physical education used by the subjects of PE K2013?, (2) Do the subjects of PE K2013 make attempts to develop the 
psychomotor, cognitive, and affective sphere of children? (3) Are teachers and schools ready to implement K2013?

Posner's [1] and Lovat and Smith [3] opinion on the steps taken towards curriculum theory and practice combined by Smith into four approaches to curriculum theory and practice, namely: (1) Curriculum as a field of knowledge to be delivered or a body of knowledge to be transmitted, (2) curriculum as an effort to achieve the end result for students or products to be achieved by learners, (3) Curriculum as process, (4) Curriculum that focuses on social justice as a praxis [4]. The curriculum as a praxis has emphasizes on several parts. First, it lays emphasis on the fact that the curriculum is a practice activity that is conducted over a definite time and place and therefore lays emphasis on the influence of social and historical conditions. The fact that theory and practice are two things that are inseparable and interconnected is also shown by the definition.

There are three curriculum models that are often used by people in the development of PE curriculum according to Wuest and Lombardo [5], these are: (1) activity based curriculum, (2) concept-based curriculum, and (3) competencybased curriculum. Based on the results of identification through the examination of physical education, both past and present, there are five curriculum models developed and used by practitioners and physical education experts, according to Jewett, Bain and Ennis [6]. The five curriculum models are as follows: (1) sports education, (2) fitness education, (3) movement analysis, development (physical education), and personal meaning. The dynamic relationship between action and reflection is used in developing the curriculum. Therefore, the curriculum is not just a collection of plans that have to be put into practice, but also produced through an active process including the planning process, implementation, and evaluation in a reciprocal and integrated manner. The sport education pattern is a pattern of teaching curriculum introduced for a physical education program where learners are not only taught how to exercise, but they are also taught how to coordinate and organize sports activities [6]. Curriculum development of PE also considers the Modern Philosophy of PE in addition to traditional philosophy and curriculum value orientation. The fact that modern philosophy grew out of numerous social, economic, educational, political, and security developments in society led to a change in the philosophy of physical education [7].

\section{METHOD}

Survey research method in the form of field study is implemented by this research [8]. Interviews, observations and quistioners are the techniques of data retrieval used. Three primary schools namely: SD Muhammadiyah Balecatur, SD Negeri Mancasan, and SD IT Jabal Nur. Research are the locations from which data is obtained in Sleman Regency. PE teachers and principals are the subjects of the research. April 2018 is the data collection time.

\section{RESULTS}

It is shown it the results that the perceptions held by teachers on the implementation of K2013 are less appropriate if the fact that the subject of physical education in elementary school still needs an introduction to the basic skills of motion rather than thematic concept K2013 is considered. Implementation of K2013 is more ambiguous because at the final exam the curriculum KTSP 2016 is used. K2013 has been implemented since 2017 in Sleman Regency. K2013 has not been held by all primary schools. K2013 has been organized only by a few schools and even in those few schools, it was held only in grade 1 and grade 4. For material, K2013 contains a lot of material but the materials aren't deep, while the material in KTSP 2006 is deep enough and more suitable for elementary schools. The amount of time issued for practice has been reduced to only 140 minutes / week from its ideal 150 minutes/week. $7 \mathrm{~m} \mathrm{x} 8 \mathrm{~m}$ is the size of the average classroom used which was ideally supposed to be $8 \mathrm{~m} \times 9 \mathrm{~m}$. In K2013, the available tools and supporting facilities are not sufficient. A graduate with 1 bachelor's degree is the average teacher. No socialization, workshop, or training has been held on K2013. The concept of curriculum application is not well understood by teachers. Curriculum preparation materials and procedures are already in existence and done in the form of Semester Program Plan, RPP, and Syllabus. Considering how RPP and RPS should be arranged, it is prepared along with team MGMP at the local UPT. Authentic assessment should be used to evaluate learning but process evaluation and test-learning outcomes are used to evaluate learning because the learning process is using KTSP 2006. Because it uses two different currents that are combined, it leads to confusion. Generally, these three primary schools have stated their readiness to implement K2013 from 2019 onwards, although, the research note proves that some of the facilities required to run K2013 are not available in the schools.

TABLE I. RESEARCH SUBJECT

\begin{tabular}{|c|l|l|l|l|}
\hline No & \multicolumn{1}{|c|}{ School } & \multicolumn{1}{|c|}{ Teachers } & $\begin{array}{c}\text { Teaching } \\
\text { Experience }\end{array}$ & Education \\
\hline 1 & $\begin{array}{l}\text { SD Muh } \\
\text { Balecatur }\end{array}$ & Suryadi, S.Pd. & 18 years & S1 UNY \\
\hline 2 & $\begin{array}{l}\text { SD Negeri } \\
\text { Mancasan }\end{array}$ & Nurhayat, S.Pd. & 5 years & S1 UNY \\
\hline 3 & $\begin{array}{l}\text { SDIT Jabal } \\
\text { Nur } \\
\text { Gamping }\end{array}$ & $\begin{array}{l}\text { Ayub T. } \\
\text { Admaja, S.Pd }\end{array}$ & 5 years & S2 UNY \\
\hline
\end{tabular}

The three primary schools are located in Sleman Regency, in Balacatur, Mancasan and Gamping areas. The following are short profiles of the three primary schools. SD Muhammadiyah Balecatur is situated at Sumbergamol, Balecatur, Gamping, Sleman District, Daerah Istimewa Yogyakarta 55295. Accreditation of schools A. KTSP 2006 is the curriculum being used. It is owned by a foundation. There are 86 male students and 81 female students. There are 8 teachers. The school has 6 classes. SD Negeri Mancasan is located at Kec. Gamping, Kab. 
Sleman, Prop. IN. Yogyakarta. Accreditation of school B. KTSP 2006 is the curriculum currently being used by the school. The school is owned by the state. There are 96 male students and 81 female students in the school. There are 9 teachers and 2 educators in the school. The school has 6 classes. SDIT Jabal Nur is located at Gamping Lor, Ambarketawang, Gamping, Sleman. Accreditation of schools: the school has not been accredited. K2013 is the curriculum currently being used by the school. The school is owned by a foundation. There are 143 male students and 108 female students in the school. There are 12 teachers in the school. 12 classes make up the study group. The following table shows the identity of the school as subjects of research including teacher name, school name, teaching experience, and last education.

TABLE II. SCHOOL PROFILE

\begin{tabular}{|c|l|c|c|c|}
\hline No & \multicolumn{1}{|c|}{ School } & Grade & Curriculum & students \\
\hline 1 & SD Muh Balecatur & A & KTSP 2006 & 167 \\
\hline 2 & SD Negeri Mancasan & B & KTSP 2006 & 177 \\
\hline 3 & $\begin{array}{l}\text { SDIT Jabal Nur } \\
\text { Gamping }\end{array}$ & Belum & K2013 & 251 \\
\hline
\end{tabular}

Furthermore, this article will answer three important study questions on problems, which need to be identify and solved urgently. The three research questions are: (1) Is the philosophy of education from physical education used by the subjects of PE K2013?, (2) Is the development of the psychomotor, cognitive, and affective sphere of children the aim if the subjects if PE K2013? (3) Are teachers and schools ready for the implementation K2013?

\section{IV.DISCUSSION}

A. Do the subjects in K2013 use the philosophy of education from the physical and physical education?

All three of the primary schools on which the research was carried out were hesitant to convey the meaning of the philosophy of physical education. It is difficult to explain the meaning of the philosophy of education through the body, according to the researcher. It is however understood by researchers that $\mathrm{PE}$ teachers from and through the body are already using this educational philosophy. The essence of the developmental model is the philosophy of education through the physical. The program is designed to organize activities and learning experiences aimed at development based on orientation of self-actualization values. The child should be mastered in the field of study, acquire important knowledge, or integration of the academic discipline as a key word for successful school success, as believed by the orientation of mastery of expertise. Creating a learning environment that recognizes and educates potential students is the obligation of the model of educational development. Melograno [8] states that the education increases the cognitive, psychomotor, and affective spheres because participants experience changes in developmental stages and growth patterns during learning. Physical education programs must be in line with the stage of development and learning level of children. The essence of education through the physical is the contribution of physical education to the level referred to. This means that basic skills are taught in elementary schools, and then different types of activities or theme units, including lifelong exercises, in high school.

Learners are placed at the core of the curriculum by the developmental model. Teachers while paying attention to the needs and interests of the child organize lessons and activities to be carried out. Learners decide the use of the movement in their lives and reflect on decisions taken. This model reflects the self-actualization value orientation that lays emphasis on individual student development [5]. The level of student development at the time is the basis, which the curriculum maker uses to plan the program.

Because of the belief that all participants' spheres are developed in a balanced manner, Ninety-five percent $(95 \%)$ of the physical education curriculums of elementary schools in the United States are in this model. The purpose of this model is Self-satisfaction, competence to perform physical activities, have individual without, socialize and determine choice responsibly, and able to integrate experience.

TABLE III. THE INSTRUMENT OF PHYLOSOPHY IDENTITY

\begin{tabular}{|c|l|l|}
\hline No & \multicolumn{1}{|c|}{ Question } & \multicolumn{1}{c|}{ Answer } \\
\hline 1 & Philosophy of PE & Education through Physical \\
\hline 2 & Value orientation & Learning Process \\
\hline 3 & Three domain of learning & Cognitive, affective, psychomotor \\
\hline 4 & Curriculum Model & K2013 and KTSP 2006 \\
\hline 5 & Method of learning & Integrated thematic-Mosston \\
\hline 6 & Assessment System & Authentic assessment \\
\hline
\end{tabular}

B. Do K2013 subjects aim to develop the psychomotor, cognitive, and affective aspects of children?

Yes. Appropriate answers to research questions that PE develops these three domains evenly. Physical education focuses on the development of aspects of physical fitness, motion skills, critical thinking skills, emotional stability, social skills, reasoning and moral action through physical activity since it is an integral part of the overall educational system (MoNE 2003: 5). A good curriculum largely influences motion skills, physical fitness, knowledge, and positive attitudes toward physical education. In other words, PE develops these three domains through physical activity.

Children's abilities, needs, concerns and interests differ from adult abilities, needs, interests and concerns. Therefore, it is certainly less suitable if the learning as pouring water from one glass to another glass. Teachers are not enough to provide a program of physical activity or sport for adults to children. Similarly, the training experience that teachers get during college is not necessarily suitable given to their students. Children need programs specifically tailored to their interests, abilities, and needs (Developmentally Appropriate Practice).

Instructionally appropriate practices whose meanings are given teaching tasks known to be the best ways of learning are also contained in the Curriculum of PE. The way of learning is 
the result of proper study or experience, which gives all students the chance to learn optimally. To attain a clearer image of the attributes of learning PE, the following describe the aspects of the curriculum that are similar.

An evaluation is needed to know if our physical education approach program is successful or whether it needs improvement. Many criteria can be used for this purpose. To that end, especially in America, the NASPE (National Association for Sport and Physical Education, 1992) has stated that "Physically Educated Person" is one of its criteria. The Physical Education program is divided into 20 characteristics, grouped into five classes and is an elaboration of the achievement of short term and long-term goals of the Physical Education program in schools as described by this criterion.

\section{Are teachers and schools ready to implement K2013?}

Generally, even though the research shows that some elements of readiness at school are not suitable for the organization of K2013, the three primary schools have declared their readiness to implement K2013 from 2019 onwards. Because subjects of physical education in elementary schools still need an introduction to the basic skills of motion rather than thematic concept, teachers' views towards the implementation of K2013 are seen as inappropriate. Implementation of K2013 is more ambiguous. Since 2017 when using the KTSP 2016 curriculum in final exams was initially implemented in Sleman Regency, not all primary schools have implemented it. K2013 has been implemented only by a few schools and even in those schools; it has only been implemented in classes 1 and 4. In K2013, the materials are very much but not comprehensive enough but that of KTSP 2006 is comprehensive and more suitable for learning in an elementary school

When considered from various aspects, one of the development process models is the curriculum as a praxis. When the process model is controlled by general principles and places emphasis on judgment and meaning making, The process model does not make explicit statements about the direction of its services when it is controlled by general principles and places emphasizes judgement and meaning making. For instance, he may use different methods, which do not make adequate references to the general human welfare and to the freedom of the human spirit. The praxis model of curriculum theory and practice takes it to the center of the process and makes an explicit commitment to emancipation. Because the praxis model of curriculum theory and practice makes an explicit commitment to emancipation, action is expressed in the form of commitment that is praxis rather than being informed.

Critical pedagogy exceeds obtaining learning experiences for the learners; it is the process of executing the student and teacher experience through discussions and negotiation, and understanding it as a problem. Therefore, it is advised that students and teachers face the real problems of their existence and relationships together because when students face real problems of existence, they will soon be able to face their oppression. The curriculum is a device formed through active processes of reciprocal and integrated planning, action, and evaluation into the process itself rather than just a set of plans, which must be implemented.

\section{CONCLUSION}

Based on the three research questions submitted, the research results are as follows:

1. It is difficult to explain the meaning of the philosophy of education using the body. However, PE teachers are already using the educational philosophy through the body according to the researchers. The essence of the development model of the PE curriculum is the philosophy of education through the physical. The contribution of physical education is the essence of education through the physical (education through the physical). This means that basic skills are taught in elementary schools, followed by different types of activities, including lifelong exercises, in high school.

2. Appropriate answers to the research show that PE develops these three domains evenly. Physical education focuses on the development of aspects of physical fitness, motion skills, critical thinking skills, emotional stability, social skills, reasoning and moral action through physical activity because it's an integral part of the education system (MoNE 2003: 5). A good curriculum influences motion skills, physical fitness, knowledge, and positive attitudes toward physical education. In other words, it can be said that PE develops these three domains through physical activity. A program specifically tailored to their interests, abilities, and needs (Developmentally Appropriate Practice) is what learners need.

3. Generally, even though the research shows that some elements of readiness at school are not suitable for the organization of K2013, the three primary schools have declared their readiness to implement K2013 from 2019 onwards. Because subjects of physical education in elementary schools still need an introduction to the basic skills of motion rather than thematic concept, teachers' views towards the implementation of K2013 are seen as inappropriate. Implementation of $\mathrm{K} 2013$ is ambiguous because in K2013, the materials are very much but not comprehensive enough but that of KTSP 2006 is comprehensive and more suitable for learning in an elementary school.

\section{REFERENCES}

[1] G. J. Posner, "Analyzing the Curriculum Third Edition". Boston: McGraw- Hill Education, 1997.

[2] L. Stenhouse, "An introduction to Curriculum Research and Development". London: Heineman, 1975.

[3] T. J. Lovat, D. L. Smith, "Curriculum: Action on Reflection. Fourth Edition". Tuggerah, N.S.W., Social Science Press, 2003.

[4] M. K. Smith, "Curriculum theory and practice the encyclopedia of informal education", www.infed.org/biblio/b-curric.htm, 1996, 2000. 
[5] D. Wuest, B. Lombardo, "Curriculum and instruction: the secondary school physical education experience". St.louis:mosby-year book, inc., 1994.

[6] A. E. Jewett, L. L. Bain, C. D. Ennis, "The curriculum process in physical education 2nd. Ed". Dubuque, WCB. Brown \& Benchmark, 1995.

[7] D. Siedentop, "Sport education: quality PE through positive sport experience". Champaign, Human Kinetics, 1994.
[8] L. E. Kelly, V. J. Melograno, Developing the physical education curriculum: An achievement-based approach. Long Grove, IL: Waveland Press, 2014.

[9] V. J. Melograno, "Designing the physical education urriculum 3rd. Ed". Cahmpign, IL, Human Kinetics, 1996.

[10] Sugiyono, "Metode Penelitian Pendidikan Pendekatan Kuantitatif, Kualitatif, dan R \& D”. Bandung, Alfabeta, 2009. 